\section{Erosion of plans for change}

\section{Hamburg}

NEARLY 40,000 students took part in a demonstration against the proposed amendments to German university regulations in Bonn during June, marking another crisis in discussions that have already dragged on for two years. The present government had commissioned a group of experts to review the existing regulations, the Hochschulrahmengesetz (HR6) and suggest improvements. These regulations were themselves a delayed response to the student unrest in the late $1960 \mathrm{~s}$, and had required four years of complex negotiation before coming into force in 1976 under the then Social Democrat/ Liberal government.

One important feature of the earlier proposals was to shift the balance within university committees to a wider group, making it possible for professors to be outvoted by the combined representation of students, assistants and non-academic personnel when they are not unanimous among themselves. The plan to return to the former system, supported by the Education Minister Dorothee Wilms (Christian Democratic Party, CDU), is the main reason for the students' protest, although they also object to the proposed introduction of a two-tier system of studies and the relaxation of rules for industrial research within universities.

The amendments would allow particularly talented students to take additional courses while the majority would have to complete their studies after six semesters. Critics feel that this would divide graduates into two groups, one of which would pick up the good jobs while the other would have to compete for an everdiminishing number of academic openings. And the planned relaxation of the regulations covering research paid for by other than official sources, usually by industry, has created intense mistrust.

Minister Wilms is becoming increasingly isolated, as the students are no longer alone in their protests. Even the West German Conference of University Rectors (WRK), once the prime mover of reform, has distanced itself from the present proposals, which it believes go too far. It is even being asked whether amendments are necessary after all. Meanwhile, the education minister is losing further ground: her hopes that the new regulations would be passed before the summer parliamentary recess have been crushed.

Even states governed by CDU have started to question the need for a change. The chief minister of Rheinland-Pfalz, Bernhard Vogel, has declared that the present regulations "are better than their reputation", on the grounds that they have enabled the universities to recover from the crisis of the $1970 \mathrm{~s}$. This reflects what most state governments are think-

\section{ing.}

The Länder, which would have to implement such new regulations as are eventually embodied in a new federal law, also feel that the change is unnecessary. Most have learned to live with the present law, with all its problems. This is exemplified by Bavaria, which has adopted a law to facilitate additional financing for research which is acceptable both to industry and the universities without having had to wait for changes in the federal law.

As time goes by, the opposition grows stronger. It is now uncertain whether the new proposals, even as amended, will be accepted by the Bundestag and the Bundesrat in the next parliamentary session. Speakers for the Social Democratic Party (SPD) have moreover declared that the plan of Dorothee Wilms to undermine the principle of the comprehensive universities (Gesamthochschule) is unacceptable, as is the proposed dissolution of the Study Reform Commission, a body concerned with the improvement of study courses. SPD even promises that the cancellation of the new regulations would have high priority if it were to return to power. After its recent electoral successes (see Nature 6 June, p.450), SPD has become very selfconfident.

Second only to the students, the loudest protests have come from the universities themselves. Having come to terms with the present law, they feel that politicians should concentrate more on the real problems: the steady erosion of financial support, the fact that 1.3 million students are enrolled on courses originally planned for 800,000 , the rapidly increasing trend to unemployment among graduates and the exceptionally discouraging prospects for promotion within the university system, where the available professorships were distributed too readily during the years of expansion.

Despite all the criticism, Minister Wilms is insisting on her plans. They may represent the only significant project available to her, especially if the lifetime of the present government is limited. But her proposals are becoming less and less acceptable as the debate continues. Yet if the new proposals are not soon made law, little will remain of their original obviously reactionary character.

Jürgen Neffe

\title{
Blood test trials inconclusive
}

\section{Washington}

THE first actual performance data on the acquired immune deficiency syndrome (AIDS) blood test are now in and they are a mixed bag. The test became available to blood banks in the United States in March following an all-out effort by the Public Health Service (PHS) and five contractor companies to meet a six-month deadline imposed a year ago by Secretary of Health and Human Services Margaret Heckler.

The performance data suggest that at least some of the concern voiced by critics of the rush effort have still not been adequately addressed. Of the 593,831 units of blood tested and reported to PHS during the four weeks beginning 22 April, 0.89 per cent tested positive in the first instance for AIDS antibody. That rate is not inconsistent with earlier estimates of the preva lence of AIDS antibody in the general population. But only 0.25 per cent of the blood samples were "repeatedly reactive" which, according to the PHS definition, means that they test positive twice in a row by the test or two times out of three if tested three times. The tests now in use all use enzyme-linked immunosorbent assays (ELISA) to detect the presence of antibody to the AIDS virus, H'TLV-III/LAV. The new data cover about 70 per cent of all blood collected in the United States during that four-week period.

Although the data say nothing about the false positive rate, one of the major concerns at the outset, the large number of samples that tested positive initially but negative when rechecked, is a worry. Test kits produced by at least two of the five companies, Abbott and Electronucleonics, showed wide variations of activity at first; Electronucleonics even had to recall from blood banks one early batch of kits on this score. Although improved quality control has done much to correct the problems, some variability apparently remains.

Meanwhile, at least some of the false positive reactions have been explained. People with certain HLA antibodies appear to react consistently positive to at least one of the tests on the market. It may be that because the test kits use virus antigen grown in human cell lines, some of the HLA antigens found on the human cell membranes are picked up in the purification of its virus protein. This problem may be eliminated when test kits derived from genetically-engineering virus antigen (grown in Escherichia coli rather than human cell lines) become available. These are being developed by Genentech and Centocor; clinical trials are expected to begin within two months.

So far, no data are available on how the ELISA test kits' performance compares with independent (and generally more reliable and more expensive and difficult) tests such as the Western blot. Some initial data will be presented at a conference at the National Institutes of Health on 31 July. These results should provide the first accurate reading on the false positive problem.
Stephen Budiansky 